\title{
Age-related changes in egg yolk composition between conventional and organic table eggs
}

\author{
Yasin Baykalir ${ }^{1}$, Ulku Gulcihan Simsek ${ }^{1}$ and Okkes Yilmaz ${ }^{2}$ \\ ${ }^{1}$ Department of Animal Science, Faculty of Veterinary Medicine, Firat University, Elazig, Turkey \\ ${ }^{2}$ Department of Biology, Faculty of Science, Firat University, Elazig, Turkey \\ e-mail: ybaykalir@firat.edu.tr
}

\begin{abstract}
The aim of this study was to investigate fatty acids, fat-soluble vitamins, malondialdehyde and cholesterol in conventional and organic eggs obtained from hens of different ages ( 30 and 60 weeks). A total of 360 egg yolks were used in this study. Polyunsaturated fatty acid, omega-3, and omega- 6 levels were higher in the organic eggs from the 30-week-old hens. The monounsaturated fatty acid level was higher in the conventional eggs but was the same between the two age groups. Cholesterol and vitamin A levels were not influenced by either the rearing system or the age of the hens. The malondialdehyde, vitamin D2, and vitamin K2 were higher in the organic eggs; however, vitamin $\mathrm{E}$ was higher in the conventional eggs. The results showed that the rearing system and age, as well as the diet, had an impact on the composition of the egg. Total levels of polyunsaturated fatty acid, omega-3, and omega- 6 are higher in organic eggs produced by younger hens.
\end{abstract}

Key words: egg components, egg quality, laying hen, rearing system

\section{Introduction}

Hen eggs are a good-quality and inexpensive food source with a moderate amount of calories (Miranda et al. 2015). Eggs comprise essential amino acids (Sarwar 1997) as well as some fatty acids, such as omega-3 ( $n-3$ ) and omega-6 ( $n-6)$ from the family of polyunsaturated fatty acids (PUFAs), which have been determined to have beneficial effects (Cherian and Quezada 2016). PUFAs have important roles in sustaining physiological conditions, such as protecting cardiovascular and nervous systems. Some chronic diseases, such as cardiovascular, diabetes, cancer, obesity, autoimmune, rheumatoid arthritis, asthma, and depression are also related to the unbalanced intake of n- 6 and $n-3$, especially when the amount of n-6>n-3 (Ristić-Medić et al. 2013). The health benefits of fatty acids have led to widespread research on fatty acid composition in animal products, leading to several attempts to enrich the $n-3$ content in animal products (Woods and Fearon 2009). These attempts are most common in the poultry industry, especially in egg production (Rymer and Givens 2005). These enriched eggs are also known as "functional eggs".

Cholesterol is an amphipathic lipid that is an important component of cell membranes and myelin, and that is necessary for the synthesis of vitamin D; bile salts; and steroids, such as glucocorticoids, estrogen, testosterone, and progesterone (Hu et al. 2010, Orth and Bellosta 2012). Chicken eggs are one of the food products that contain a high amount of cholesterol (200-300 mg/100g); therefore, eggs have been deemed by health and nutrition experts for several years as a controversial food based on presumptions that they led to cardiovascular diseases. However, some studies have proved that egg consumption has limited effects on blood cholesterol and cardiovascular disease (Eilat-Adar et al. 2013, Li et al. 2013).

Eggs also contain 18 vitamins, but their content depends on environmental factors, the hen's diet, laying hen strain, and the hen's age. The 18 vitamins, plus A, D, B2, B12, folate, biotin, pantothenic acid, and choline are those most commonly found in the egg (Miranda et al. 2015). In addition, fat-soluble vitamins $\mathrm{E}$ and $\mathrm{K}$ found in eggs, and vitamins $A$ and $E$ are known to be antioxidant agents that protect against lipid peroxidation in foods. These vitamins are often added to the hen's feed to both inhibit egg deterioration by prolonging the shelf life of the eggs and enrich the eggs with both vitamins (Mohiti-Asli et al. 2008, Shahryar et al. 2010, İlhan and Bülbül 2016). In addition, the main source of vitamin K in the hen's diet is green forage material (Bauernfeind and De Ritter 2018).

Lipid oxidation is one of the main causes of shorter shelf-life for many foods, especially those containing fat. As a result of this oxidation, the three-carbon dialdehyde, malondialdehyde (MDA), is produced that can damage an organism's proteins and DNA. Although spectrophotometric measurements of MDA are widely used, high-performance liquid chromatography (HPLC) has better sensitivity and specificity for measuring MDA in foods (Papastergiadis et al. 2012). 


\section{AGRICULTURAL AND FOOD SCIENCE}

Y. Baykalir et al. (2020) 29: 307-317

The aims of organic farming are to protect natural resources and animal welfare using appropriate ecological methods, and consumers accept organic foods as good-quality products (Samman et al. 2009, Radu-Rusu et al. 2014). Quality, nutritional value, and safety are the most important factors that affect the food preferences of the consumer; however, there are limited studies comparing organic and conventional foods in point of food composition. The positive effects of organic feed on an animal's performance, health, and nutritional composition have been determined; however, feeding a strictly organic diet has significant challenges. It is vital that the organic farming sectors meet consumer demands in a sustainable, safe, and affordable manner, while maintaining consumer trust and confidence in the food supply chain (Kristiansen et al. 2006). Organically reared laying hens have been shown to produce more eggs (Baykalir and Simsek 2018), and several reports have suggested that organic rearing has some effects on the characteristics that affect egg quality. Organically fed laying hens produce heavier eggs with heavier yolks (Baykalir and Simsek 2018); however, one study found that the weight of conventional and organic eggs were similar (Mugnai et al. 2009). It has been noted that organically fed rabbits have a lower mortality rate (Vogtmann 1998), and that organically fed rats and chickens have a higher immune capacity, than those conventionally reared (Lauridsen et al. 2005, Huber et al. 2010). The nutritional composition of animal products is influenced mainly by animal strain, diet, and age (Scheideler et al. 1998). In studies conducted on observing age-related changes in the fatty acid composition of the eggs, total PUFA, n-6, and n-3 are reportedly high in the eggs of young hens (Liu and Li 1996, Nielsen 1998); however, there is limited data on age-related changes in the levels of vitamins A, D, E, and $\mathrm{K}$ and of cholesterol and MDA in these eggs as well as those from conventional and organic rearing systems.

The aim of the current study was to investigate the effect of conventional and organic rearing systems on some of the nutrients in egg yolks in Bovans White commercial layer hens. The present paper also deals with the study of the effect of hen age on the egg composition.

\section{Materials and methods}

\section{Eggs sampling and experimental design}

The study was conducted at a commercial egg production company in Turkey. The research related to animals' use has complied with all the relevant national regulations and institutional policies for the care and use of animals (permission no: 05.11.2014/206). The study comprised 360 eggs divided into 4 groups (conventional cage and 30-week-old hens, conventional cage and 60-week-old, organically reared and 30-week-old, organically reared and 60-week-old) of 90 eggs each that were obtained from Bovans White commercial layer hybrid. The hens were provided feed and drinking water ad libitum and similar ingredients were used in the diets of the hens in both the conventional cage and organic systems. The feed was produced at the feed mill at the production company in accordance with National Research Council (NRC 1994) standards. The composition of the hens' diet is provided in Table 1. The eggs were randomly collected from the two systems, which included both 30 and 60 -week-old hens. This study planned and conducted on the same rearing season to avoid any seasonal effects on both the system and age group.

The conventional cages at the production company comprised four tiers, each $70 \mathrm{~cm}$ wide by $55 \mathrm{~cm}$ long by 50 $\mathrm{cm}$ high. In this system, the flock size was 40000 hens and each tier housed 7 hens. Each cage unit had 3 nipple drinkers and a $70-\mathrm{cm}$-long $(10 \mathrm{~cm} / \mathrm{bird})$ trough-type feeder. Manure was removed from the house using scraper belts. Artificial lighting was provided in the cages during the laying period. An 8-h light/16-h dark period was implemented for 25 weeks. The eggs were automatically collected using egg belts in this system.

Organic egg production in the company is made according to specific legislation that was adopted from the directive of the European Union 99/74/EC. Each organic house was established on an enclosed litter-floor pen of 560 $\mathrm{m}^{2}\left(5-6 \mathrm{bird} / \mathrm{m}^{2}\right)$ and an outdoor area of $12000 \mathrm{~m}^{2}\left(4 \mathrm{~m}^{2}\right.$ per hen) for 3000 hens. The outdoor area was covered with natural vegetation. Pop-holes were placed along one side of the house to provide the hens with free access to the outdoor area on sunny days. The floor pen had 120 circular hanging feeders and 200 nipple drinkers. The lighting regime was similar to that of the conventional cage system; an 8-h light/16-h dark period was used in enclosed litter-floor pens. 
AGRICULTURAL AND FOOD SCIENCE

Y. Baykalir et al. (2020) 29: 307-317

Table 1. Composition of conventional and organic feeds in studied laying periods

\begin{tabular}{|c|c|c|c|c|}
\hline \multirow[b]{2}{*}{ Feed ingredients (\%) } & \multicolumn{2}{|c|}{$18-36$ weeks } & \multicolumn{2}{|c|}{ 52-65 weeks } \\
\hline & Conventional & Organic & Conventional & Organic \\
\hline Maize* & 27.00 & 27.00 & 27.40 & 27.40 \\
\hline Wheat* & 20.00 & 20.00 & 24.85 & 24.85 \\
\hline Wheat bran* & 9.00 & 9.00 & 5.68 & 5.26 \\
\hline Soybean meal* (\%48 CP) & 16.20 & 18.00 & 16.00 & 17.50 \\
\hline Sunflower meal* (\%32 CP) & 6.64 & 3.00 & 5.90 & 2.50 \\
\hline Maize gluten*(\%43 CP) & 4.76 & 4.76 & 3.00 & 3.00 \\
\hline Alfalfa flour* & - & 2.09 & - & 2.50 \\
\hline Sunflower oil * & 5.60 & 5.60 & 6.02 & 6.00 \\
\hline DL-methionine & 0.12 & - & 0.08 & - \\
\hline L-lysine hydrochloride & 0.01 & - & - & - \\
\hline L-threonine & 0.01 & - & - & - \\
\hline L-tryptophan & 0.01 & - & - & - \\
\hline Dicalcium phosphate & 1.63 & 1.63 & 1.41 & 1.41 \\
\hline Ground limestone & 8.60 & 8.50 & 9.13 & 9.05 \\
\hline Sodium bicarbonate & 0.10 & 0.10 & 0.25 & 0.25 \\
\hline Salt & 0.16 & 0.16 & - & - \\
\hline Vitamin-mineral mixture** & 0.16 & 0.16 & 0.28 & 0.28 \\
\hline \multicolumn{5}{|l|}{ Nutrient composition (\%) } \\
\hline Dry matter & 90.9 & 90.9 & 90.8 & 90.9 \\
\hline Crude protein & 17.8 & 17.8 & 16.7 & 16.7 \\
\hline Total phosphorus & 0.38 & 0.38 & 0.34 & 0.34 \\
\hline Calcium & 3.76 & 3.75 & 3.90 & 3.91 \\
\hline Sodium & 0.15 & 0.15 & 0.15 & 0.15 \\
\hline Methionine+cysteine & 0.73 & 0.70 & 0.65 & 0.56 \\
\hline Lysine & 0.84 & 0.86 & 0.84 & 0.84 \\
\hline Threonine & 0.67 & 0.67 & 0.65 & 0.64 \\
\hline Tryptophan & 0.24 & 0.23 & 0.24 & 0.23 \\
\hline $\mathrm{ME}, \mathrm{Kcal} / \mathrm{kg}$ & 2718 & 2726 & 2741 & 2788 \\
\hline
\end{tabular}

$\mathrm{CP}=$ Crude protein; *Organic raw materials were used in the organic diet.; **Vitamin mix (per $2.5 \mathrm{~kg}$ ): vitamin A, $12000000 \mathrm{IU}$; vitamin D3, 2000000 IU; vitamin E, $35000 \mathrm{mg}$; vitamin K3, $4000 \mathrm{mg}$; vitamin B1, $3000 \mathrm{mg}$; vitamin B2, $7000 \mathrm{mg}$; niacin, $20000 \mathrm{mg}$; calcium D- pantothenate, $10000 \mathrm{mg}$; vitamin B6, $5000 \mathrm{mg}$; vitamin B12, $15 \mathrm{mg}$; folic acid, $1000 \mathrm{mg}$; D-biotin, $45 \mathrm{mg}$; vitamin C, $50000 \mathrm{mg}$; choline chloride, 125000 mg; canthaxanthin, $2500 \mathrm{mg}$; apo carotenoic acid ester, $500 \mathrm{mg}$. Conventional diet mineral mix (per $1 \mathrm{~kg}$ ): manganese, $80000 \mathrm{mg}$; ferrous, $60000 \mathrm{mg}$; zinc, $60000 \mathrm{mg}$; copper, $5000 \mathrm{mg}$; cobalt, $200 \mathrm{mg}$; iodine, $1000 \mathrm{mg}$; selenium, $150 \mathrm{mg}$. Organic diet mineral mix (per $1 \mathrm{~kg}$ ): organic manganese, $20000 \mathrm{mg}$; organic ferrous, $20000 \mathrm{mg}$; organic zinc, $20000 \mathrm{mg}$; organic copper, $2000 \mathrm{mg}$; organic selenium, $200 \mathrm{mg}$

\section{Sample processing for analysis}

Each egg was broken and each yolk was separated from the albumen. The yolks were rolled on filter paper to remove any albumen residues. From each system and age group, 9 egg yolks from each sample were pooled in $50-\mathrm{ml}$ tubes and gently mixed. Ten samples were prepared for each analysis. Forty tubes were sealed and frozen to be analyzed. The yolks were extracted and processed according to Hara and Radin (1978). Two aliquots of $5 \mathrm{ml}$ extract were transferred into sealed tubes and stored at $-25^{\circ} \mathrm{C}$ until for fatty acid composition; cholesterol; vita$\operatorname{mins} \mathrm{A}, \mathrm{D}, \mathrm{E}$, and $\mathrm{K}$; and MDA analysis.

\section{Preparation of fatty acid methyl esters}

Fatty acid methyl esters (FAMEs) were prepared according to Christie (1989) by adding $5 \mathrm{ml} 2 \%$ methanolic sulfuric acid solution to $5 \mathrm{ml}$ extract and vortexed. This mixture was stored at $55^{\circ} \mathrm{C}$ for $14-15 \mathrm{~h}$ for the methylation. The $5 \mathrm{ml} 5 \% \mathrm{NaCl}$ was added to the samples when they reached room temperature. FAMEs were extracted using $\mathrm{n}$-hexane, and the hexane phase was transferred into new tubes to which $2 \% \mathrm{KHCO}_{3}$ was added. After $3 \mathrm{~h}$ (for completion of phase segregation), the samples were stored at $37^{\circ} \mathrm{C}$ for $2 \mathrm{~d}$. At the end of $2 \mathrm{~d}, 1 \mathrm{ml}$ heptane was added to the samples and they were put into vials for analysis of fatty acid composition with gas chromatography (GC). 


\section{AGRICULTURAL AND FOOD SCIENCE}

\section{Gas chromatography}

After the fatty acids were converted into methyl esters, they were analyzed using the Shimadzu GC-17A (Shimadzu Corporation, Kyoto, Japan). For the analysis, the SPTM-28 fused silica capillary column (Sigma-Aldrich Co. LLC, Taufkirchen, Germany) with a film $0.2 \mu \mathrm{m}$ thick, $0.25 \mathrm{~mm}$ in diameter, and $30 \mathrm{~m}$ long was used. During the analysis, the column temperature was kept at $120-220^{\circ} \mathrm{C}$, the injection temperature at $240^{\circ} \mathrm{C}$, and the detector temperature at $280^{\circ} \mathrm{C}$. The temperature was increased by $5^{\circ} \mathrm{C} \mathrm{min}-1$ until it reached $200{ }^{\circ} \mathrm{C}$ and by $4{ }^{\circ} \mathrm{C} \mathrm{min}{ }^{-1}$ from $200^{\circ} \mathrm{C}$ to $220^{\circ} \mathrm{C}$. Nitrogen was used as carrier gas. A standard FAME mixture was injected to determine the retention time of each fatty acid in the samples. The values of fatty acids are given as percentages of total fatty acids (Tvrzická et al. 2002).

\section{HPLC analyses of cholesterol, vitamins A, D, E, K and MDA}

The $10 \%$ methanolic potassium hydroxide solution was used for the extraction of the samples. All samples were equalized with $\mathrm{n}$-hexane for the extraction of non-saponified lipophilic molecules. After this process, $1 \mathrm{ml}$ acetonitrile/methanol was added to the residue and the solution transferred into autosampler vials for analysis. A Shimadzu VP series HPLC instrument (Shimadzu Corporation) was used to conduct the analyses with LC Solution. The detection wavelength for vitamin A was at $326 \mathrm{~nm}$ (Sánchez-Machado et al. 2002), and that for cholesterol and vitamins D, E, K was set at $202 \mathrm{~nm}$ (Lopez-Cervantes et al. 2006). The values for cholesterol and vitamins D,

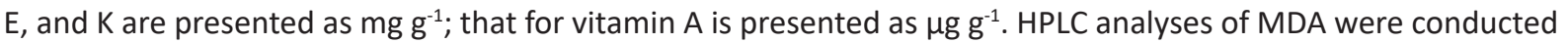
according to Karatas et al. (2002). The $1 \mathrm{ml}$ of supernatant from each sample was analyzed using the Shimadzu VP series full-automatic HPLC system (Shimadzu Corporation). The DAD detector and a column of ODS-3 (15 $\times 4.6$ $\mathrm{cm}, 5 \mu \mathrm{m}$ ) were used for this analysis at a wavelength of $244 \mathrm{~nm}$. MDA standards (Sigma-Aldrich) were prepared to total $2.92 \mathrm{\mu g} \mathrm{ml}^{-1}$, and the MDA levels of the samples were calculated as $\mathrm{nmol} \mathrm{g}$.

\section{Statistical analysis}

The $2 \times 2$ factorial design was used with a General Linear Model and the rearing systems (conventional cage and organic) and age groups ( 30 and 60 weeks) were the main effects. SPSS 22 (IBM Corp., Armonk NY, USA) was used for the analyses. The data are represented as the mean and standard error of the mean (SEM). $p \leq 0.05$ was considered statistically significant (Collins et al. 2009).

\section{Results}

Fatty acid composition: cholesterol and vitamins; A (retinol), D (D2), E ( $\alpha$ and $\delta$ tocopherols), and K (K2) of the feed samples are presented in Tables 2 and 3, respectively.

Table 2. Fatty acid composition of conventional and organic feeds in studied laying periods

\begin{tabular}{|c|c|c|c|c|}
\hline Fatty acids (\%) & Conventional & Organic & 18-36 weeks & 52-65 weeks \\
\hline C $16: 0$ & 12.70 & 13.51 & 12.61 & 13.60 \\
\hline C 18:0 & 4.00 & 4.17 & 4.20 & 3.98 \\
\hline C 20:0 & 0.17 & - & - & - \\
\hline C $22: 0$ & 0.16 & 0.32 & 0.31 & 0.17 \\
\hline C 18:1n-9cis & 27.01 & 24.41 & 24.69 & 26.93 \\
\hline C 18:2n-6cis & 51.64 & 52.27 & 53.18 & 50.73 \\
\hline C $18: 3 n-3$ & 3.94 & 4.98 & 4.66 & 4.22 \\
\hline C $18: 3 n-6$ & 0.38 & 0.34 & 0.35 & 0.37 \\
\hline ¿SFA & 17.03 & 18.00 & 17.12 & 17.75 \\
\hline ¿MUFA & 27.01 & 24.41 & 24.69 & 26.93 \\
\hline$\Sigma$ PUFA & 55.96 & 57.59 & 58.19 & 55.32 \\
\hline$\sum n-3$ & 3.94 & 4.98 & 4.66 & 4.22 \\
\hline$\sum n-6$ & 52.02 & 52.61 & 53.53 & 51.10 \\
\hline$\sum n-6 / n-3$ & 13.20 & 10.56 & 11.48 & 12.10 \\
\hline
\end{tabular}


Table 3. Levels of cholesterol and vitamins A (retinol), D (D2), E ( $\alpha$ - and $\delta$-tocopherols), and K (K2) in the feeds

\begin{tabular}{lcccc}
\hline \multicolumn{1}{c}{ Parameters } & $\begin{array}{c}\text { Conventional } \\
18-36 \text { weeks }\end{array}$ & $\begin{array}{c}\text { Organic } \\
\text { 18-36 weeks }\end{array}$ & $\begin{array}{c}\text { Conventional } \\
\text { 52-65 weeks }\end{array}$ & $\begin{array}{c}\text { Organic } \\
\text { 52-65 weeks }\end{array}$ \\
\hline Cholesterol $\left(\mathrm{mg} \mathrm{g}^{-1}\right)$ & 0.190 & 0.163 & 0.450 & 0.480 \\
Retinol $\left(\mathrm{\mu g} \mathrm{g}^{-1}\right)$ & 8.25 & 4.25 & 5.75 & 12.25 \\
Vitamin D2 $\left(\mathrm{mg} \mathrm{g}^{-1}\right)$ & 0.152 & 0.098 & 0.134 & 0.154 \\
$\alpha$-tocopherol $\left(\mathrm{mg} \mathrm{g}^{-1}\right)$ & 0.090 & 0.033 & 0.007 & 0.154 \\
$\delta$-tocopherol $\left(\mathrm{mg} \mathrm{g}^{-1}\right)$ & 0.020 & 0.025 & 0.008 & 0.038 \\
Vitamin K2 $\left(\mathrm{mg} \mathrm{g}^{-1}\right)$ & 0.040 & 0.043 & 0.020 & 0.055 \\
\hline
\end{tabular}

The saturated fatty acid (SFA) levels in the egg yolks are shown in Table 4. Palmitic acid (C 16:0) and stearic acid (C 18:0) were determined to be high in the yolks with significant differences in these between rearing systems and hen age $(p<0.05)$. Margaric acid (C 17:0) was affected only by age and was higher in the eggs from hens 30 weeks old $(0.37 \%)$ than in those from hens 60 weeks old (0.15\%). Myristic (C 14:0) and behenic acids (C 22:0) were not influenced by either the rearing system and hen age and were not significantly different $(p>0.05)$.

Table 4. Levels of saturated fatty acids in the egg yolks (\%)

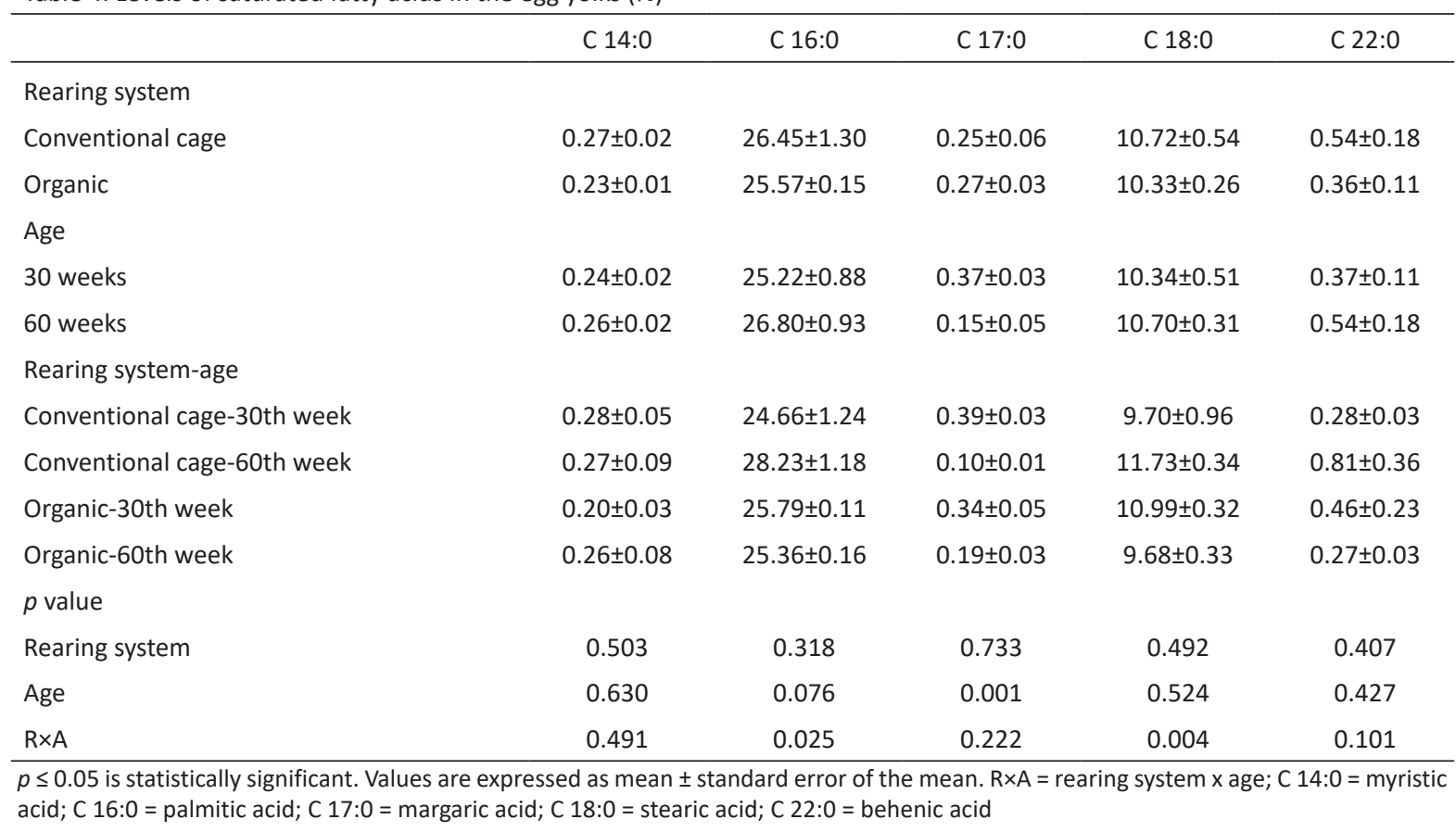

The level of monounsaturated fatty acids (MUFAs) in the egg yolks are presented in Table 5, with oleic acid (C $18: 1 n-9$ cis) being one of the higher MUFAs found in the samples. Nervonic acid (C $24: 1 n-9)$ was influenced by both rearing system and age and was found to be higher in eggs from the conventional system $(0.92 \%)$ than in those from the organic system $(0.47 \%)$ but lower in eggs from the younger hens $(0.55 \%)$ than in those from the older hens (0.83\%). This was a significant difference $(p<0.001)$. Palmitoleic acid (C 16:1n-7), oleic acid (C 18:1n-9cis), and elaidic acid (C 18:1n-9trans) levels were similar among the groups ( $p>0.05)$.

The PUFA levels in the examined egg yolks are presented in Table 6 with linoleic acid (C 18:2n-6cis) levels being highest among them. Rearing systems and hen age had an effect on levels of both linoleic (C 18:2n-6cis) and alpha-linolenic acids (ALA-18:3n-3) ( $p<0.05)$. Linoleic acid (C 18:2n-6cis) was higher in the organic eggs $(p<0.05)$. There were no differences among in both the rearing system and age in the levels of eicosadienoic acid (C 20:2n6), gamma linolenic acid (C 18:3n-6), dihomogammalinolenic acid (C 20:3), cervonic acid (C 20:4n-6), or arachidonic acid (C 22:6n-3) ( $p>0.05)$.

Total SFA, MUFA, PUFA, $n-3, n-6$, and $n-6 / n-3$ in the eggs are presented in Table 7. Rearing system and age were found to have an effect on total PUFA, $n-3$, and $n-6$ values $(p<0.05)$. In the conventional system, total levels of PUFA (23.19\%), n-3 (1.81\%), and n-6 (21.22\%) were lower $(p<0.05)$ than those in the organic system $(27.03,2.17$, 


\section{AGRICULTURAL AND FOOD SCIENCE}

Y. Baykalir et al. (2020) 29: 307-317

and $24.70 \%$, respectively); however, these values decreased with hen age (30 weeks: $26.99,2.26$, and $24.53 \%$, respectively; 60 weeks: $23.24,1.73$, and $21.40 \%$, respectively) $(p<0.05)$. We also observed that total SFA was affected by both the rearing system and age $(p<0.01)$. Total MUFA was significantly affected by the rearing system, with its value being higher in the conventional system $(36.57 \%)$ than in the organic system $(36.18 \%)(p<0.05)$. The effect of age on total $n-6 / n-3$ was also significant $(p<0.01)$, with $n-6 / n-3$ levels increasing with hen age. There was also a significant effect when the rearing system was combined with age $(p<0.05)$.

\begin{tabular}{|c|c|c|c|c|}
\hline & C $16: 1 n-7$ & C $18: 1 n-9 c$ & C $18: 1 n-9 t$ & C $24: 1 n-9$ \\
\hline \multicolumn{5}{|l|}{ Rearing system } \\
\hline Conventional cage & $2.78 \pm 0.20$ & $32.47 \pm 1.90$ & $2.38 \pm 1.23$ & $0.92 \pm 0.08$ \\
\hline Organic & $2.43 \pm 0.08$ & $31.32 \pm 1.26$ & $1.95 \pm 1.19$ & $0.47 \pm 0.01$ \\
\hline \multicolumn{5}{|l|}{ Age } \\
\hline 30 weeks & $2.51 \pm 0.14$ & $30.47 \pm 1.68$ & $2.91 \pm 1.47$ & $0.55 \pm 0.03$ \\
\hline 60 weeks & $2.70 \pm 0.17$ & $33.32 \pm 1.48$ & $1.42 \pm 0.84$ & $0.83 \pm 0.09$ \\
\hline \multicolumn{5}{|l|}{ Rearing system-age } \\
\hline Conventional cage-30th week & $2.64 \pm 0.26$ & $31.57 \pm 2.43$ & $2.64 \pm 1.85$ & $0.60 \pm 0.07$ \\
\hline Conventional cage-60th week & $2.91 \pm 0.33$ & $33.37 \pm 3.00$ & $2.12 \pm 1.70$ & $1.25 \pm 0.05$ \\
\hline Organic-30th week & $2.37 \pm 0.12$ & $29.36 \pm 2.39$ & $3.19 \pm 2.38$ & $0.51 \pm 0.02$ \\
\hline Organic-60th week & $2.49 \pm 0.11$ & $33.27 \pm 0.49$ & $0.71 \pm 0.03$ & $0.42 \pm 0.02$ \\
\hline \multicolumn{5}{|l|}{$p$ value } \\
\hline Rearing system & 0.134 & 0.615 & 0.804 & 0.000 \\
\hline Age & 0.402 & 0.218 & 0.392 & 0.000 \\
\hline$R \times A$ & 0.738 & 0.647 & 0.574 & 0.000 \\
\hline
\end{tabular}

$p \leq 0.05$ is statistically significant. Values are expressed as the mean \pm standard error of the mean. $\mathrm{R} \times \mathrm{A}=$ rearing system $\times$ age; C 16:1n-7 = palmitoleic acid; C 18:1n-9c = oleic acid; C 18:1n-9t = elaidic acid; C 24:1n-9 = nervonic acid

Table 6. Levels of polyunsaturated fatty acids in the egg yolks (\%)

\begin{tabular}{|c|c|c|c|c|c|c|c|}
\hline & C $18: 2 n-6 c$ & C $20: 2 n-6$ & C $18: 3 n-3$ & C $18: 3 n-6)$ & C $20: 3$ & C 20:4n-6 & C 22:6n-3 \\
\hline \multicolumn{8}{|l|}{ Rearing system } \\
\hline Conventional cage & $18.28 \pm 1.55$ & $0.16 \pm 0.05$ & $0.69 \pm 0.19$ & $0.14 \pm 0.05$ & $0.15 \pm 0.05$ & $2.62 \pm 0.25$ & $1.13 \pm 0.08$ \\
\hline Organic & $21.54 \pm 0.22$ & $0.22 \pm 0.01$ & $0.85 \pm 0.05$ & $0.13 \pm 0.01$ & $0.16 \pm 0.01$ & $2.80 \pm 0.18$ & $1.32 \pm 0.06$ \\
\hline \multicolumn{8}{|l|}{ Age } \\
\hline 30 weeks & $21.32 \pm 1.40$ & $0.23 \pm 0.01$ & $0.94 \pm 0.17$ & $0.16 \pm 0.01$ & $0.19 \pm 0.02$ & $2.80 \pm 0.21$ & $1.32 \pm 0.08$ \\
\hline 60 weeks & $18.50 \pm 0.75$ & $0.15 \pm 0.05$ & $0.60 \pm 0.09$ & $0.11 \pm 0.05$ & $0.12 \pm 0.05$ & $2.63 \pm 0.21$ & $1.12 \pm 0.06$ \\
\hline \multicolumn{8}{|l|}{ Rearing system-age } \\
\hline $\begin{array}{l}\text { Conventional cage-30th } \\
\text { week }\end{array}$ & $21.60 \pm 2.84$ & $0.22 \pm 0.02$ & $1.10 \pm 0.33$ & $0.19 \pm 0.02$ & $0.20 \pm 0.04$ & $2.66 \pm 0.30$ & $1.22 \pm 0.14$ \\
\hline $\begin{array}{l}\text { Conventional cage-60th } \\
\text { week }\end{array}$ & $14.96 \pm 0.22$ & $0.10 \pm 0.01$ & $0.27 \pm 0.11$ & $0.10 \pm 0.01$ & $0.10 \pm 0.01$ & $2.59 \pm 0.40$ & $1.03 \pm 0.08$ \\
\hline Organic-30th week & $21.05 \pm 0.24$ & $0.24 \pm 0.01$ & $0.77 \pm 0.07$ & $0.14 \pm 0.01$ & $0.19 \pm 0.01$ & $2.93 \pm 0.31$ & $1.42 \pm 0.09$ \\
\hline Organic-60th week & $22.04 \pm 0.25$ & $0.21 \pm 0.03$ & $0.93 \pm 0.07$ & $0.12 \pm 0.02$ & $0.13 \pm 0.02$ & $2.67 \pm 0.17$ & $1.21 \pm 0.08$ \\
\hline \multicolumn{8}{|l|}{$p$ value } \\
\hline Rearing system & 0.029 & 0.248 & 0.374 & 0.783 & 0.911 & 0.577 & 0.063 \\
\hline Age & 0.056 & 0.152 & 0.074 & 0.332 & 0.175 & 0.582 & 0.055 \\
\hline $\mathrm{R} \times \mathrm{A}$ & 0.011 & 0.423 & 0.010 & 0.557 & 0.746 & 0.759 & 0.902 \\
\hline
\end{tabular}


Table 7. Total SFA, MUFA, PUFA, n-3, n-6, n-6/n-3 in the egg yolks (\%)

\begin{tabular}{|c|c|c|c|c|c|c|}
\hline & $\sum$ SFA & $\sum$ MUFA & $\sum$ PUFA & $\sum n-3$ & $\sum n-6$ & $\sum n-6 / n-3$ \\
\hline \multicolumn{7}{|l|}{ Rearing system } \\
\hline Conventional cage & $38.24 \pm 1.37$ & $38.57 \pm 0.97$ & $23.19 \pm 1.63$ & $1.81 \pm 0.17$ & $21.22 \pm 1.47$ & $12.90 \pm 0.85$ \\
\hline Organic & $36.79 \pm 0.38$ & $36.18 \pm 0.44$ & $27.03 \pm 0.27$ & $2.17 \pm 0.05$ & $24.70 \pm 0.22$ & $11.50 \pm 0.26$ \\
\hline \multicolumn{7}{|l|}{ Age } \\
\hline 30 weeks & $36.56 \pm 1.06$ & $36.46 \pm 0.62$ & $26.99 \pm 1.40$ & $2.26 \pm 0.13$ & $24.53 \pm 1.28$ & $10.99 \pm 0.29$ \\
\hline 60 weeks & $38.47 \pm 0.93$ & $38.29 \pm 0.89$ & $23.24 \pm 0.89$ & $1.73 \pm 0.11$ & $21.40 \pm 0.79$ & $13.40 \pm 0.79$ \\
\hline \multicolumn{7}{|l|}{ Rearing system-age } \\
\hline Conventional cage-30th week & $35.33 \pm 2.07$ & $37.47 \pm 1.02$ & $27.20 \pm 2.83$ & $2.32 \pm 0.24$ & $24.69 \pm 2.60$ & $10.70 \pm 0.32$ \\
\hline Conventional cage-60th week & $41.16 \pm 1.43$ & $39.67 \pm 1.62$ & $19.17 \pm 0.48$ & $1.30 \pm 0.13$ & $17.76 \pm 0.41$ & $15.10 \pm 1.43$ \\
\hline Organic-30th week & $37.79 \pm 0.43$ & $35.44 \pm 0.61$ & $26.76 \pm 0.46$ & $2.20 \pm 0.10$ & $24.37 \pm 0.37$ & $11.28 \pm 0.49$ \\
\hline Organic-60th week & $35.78 \pm 0.48$ & $36.91 \pm 0.59$ & $27.31 \pm 0.29$ & $2.14 \pm 0.04$ & $25.04 \pm 0.23$ & $11.71 \pm 0.18$ \\
\hline \multicolumn{7}{|l|}{$P$ value } \\
\hline Rearing system & 0.269 & 0.028 & 0.011 & 0.018 & 0.013 & 0.078 \\
\hline Age & 0.149 & 0.088 & 0.014 & 0.001 & 0.024 & 0.003 \\
\hline$R \times A$ & 0.004 & 0.725 & 0.005 & 0.002 & 0.007 & 0.015 \\
\hline
\end{tabular}

Table 8 presents the levels of MDA; cholesterol; and vitamins A (retinol), D (D2), E ( $\alpha$ and $\delta$ tocopherols), and $K$ (K2) in the egg yolks. MDA, $\alpha$-tocopherol $(p<0.01)$, and vitamin D2 $(p<0.001)$ were influenced by both the type of rearing system and hen age. There were significant differences in levels of $\mathrm{MDA}(p<0.01)$ and vitamin $\mathrm{D} 2(p<0.001)$, with MDA being higher in the organic eggs $\left(142.76 \mathrm{nmol} \mathrm{g}^{-1}\right)$ than in the conventionally produced eggs (116.85 $\left.\mathrm{nmol} \mathrm{g}^{-1}\right)$. In addition, MDA levels in eggs were observed to increase with hen age. MDA levels were low in the eggs from the younger hens $\left(116.73 \mathrm{nmol} \mathrm{g}^{-1}\right)$ and high in the eggs from the older hens $\left(144.06 \mathrm{nmol} \mathrm{g} \mathrm{g}^{-1}\right)$. Vitamin K2 was affected only by the rearing system $(p<0.01)$, which was also the case for the levels of $\alpha$-tocopherol. Vitamin $\mathrm{K} 2$ levels were higher in the organic eggs $\left(0.23 \mathrm{mg} \mathrm{g}^{-1}\right)$ than in eggs conventionally produced $\left(0.17 \mathrm{mg} \mathrm{g}^{-1}\right)$; however, $\alpha$-tocopherol was higher in eggs produced conventionally $\left(0.17 \mathrm{mg} \mathrm{g}^{-1}\right)$ than in organic eggs $\left(0.12 \mathrm{mg} \mathrm{g}^{-1}\right)$. Levels of $\alpha$-tocopherol were also higher in eggs from the older hens $\left(0.17 \mathrm{mg} \mathrm{g}^{-1}\right)$ than in those from the younger hens $\left(0.12 \mathrm{mg} \mathrm{g}^{-1}\right)$.

Table 8. Amounts of MDA, cholesterol, and vitamins A (retinol), D (D2), E ( $\alpha$ and $\delta$ tocopherols), and $K$ (K2) in the egg yolks

\begin{tabular}{|c|c|c|c|c|c|c|c|}
\hline & $\begin{array}{c}\text { MDA } \\
\left(\mathrm{nmol} \mathrm{g}^{-1}\right)\end{array}$ & $\begin{array}{l}\text { Cholesterol } \\
\left(\mathrm{mg} \mathrm{g}^{-1}\right)\end{array}$ & $\begin{array}{l}\text { Retinol } \\
\left(\mu g^{-1}\right)\end{array}$ & $\begin{array}{l}\text { Vitamin D2 } \\
\left(\mathrm{mg} \mathrm{g}^{-1}\right)\end{array}$ & $\begin{array}{l}\alpha \text {-tocopherol } \\
\left(\mathrm{mg} \mathrm{g}^{-1}\right)\end{array}$ & $\begin{array}{c}\delta \text {-tocopherol } \\
\left(\mathrm{mg} \mathrm{g}^{-1}\right)\end{array}$ & $\begin{array}{l}\text { Vitamin K2 } \\
\left(\mathrm{mg} \mathrm{g}^{-1}\right)\end{array}$ \\
\hline \multicolumn{8}{|l|}{ Rearing system } \\
\hline Conventional cage & $116.85 \pm 5.93$ & $28.23 \pm 1.13$ & $21.12 \pm 0.42$ & $0.050 \pm 0.010$ & $0.170 \pm 0.014$ & $0.260 \pm 0.025$ & $0.17 \pm 0.01$ \\
\hline Organic & $142.76 \pm 8.10$ & $30.26 \pm 0.47$ & $21.26 \pm 0.40$ & $0.100 \pm 0.003$ & $0.120 \pm 0.006$ & $0.220 \pm 0.003$ & $0.23 \pm 0.01$ \\
\hline \multicolumn{8}{|l|}{ Age } \\
\hline 30 weeks & $116.73 \pm 5.75$ & $30.26 \pm 0.52$ & $20.95 \pm 0.45$ & $0.090 \pm 0.003$ & $0.120 \pm 0.007$ & $0.240 \pm 0.014$ & $0.22 \pm 0.01$ \\
\hline 60 weeks & $144.06 \pm 8.21$ & $28.22 \pm 1.11$ & $21.43 \pm 0.36$ & $0.070 \pm 0.010$ & $0.170 \pm 0.014$ & $0.240 \pm 0.020$ & $0.19 \pm 0.01$ \\
\hline \multicolumn{8}{|l|}{ Rearing system-age } \\
\hline $\begin{array}{l}\text { Conventional cage- } \\
\text { 30th week }\end{array}$ & $117.94 \pm 10.15$ & $29.57 \pm 0.75$ & $21.15 \pm 0.76$ & $0.080 \pm 0.005$ & $0.151 \pm 0.008$ & $0.246 \pm 0.029$ & $0.18 \pm 0.01$ \\
\hline $\begin{array}{l}\text { Conventional cage- } \\
60 \text { th week }\end{array}$ & $115.67 \pm 6.17$ & $26.89 \pm 2.12$ & $21.09 \pm 0.40$ & $0.001 \pm 0.001$ & $0.201 \pm 0.026$ & $0.274 \pm 0.040$ & $0.16 \pm 0.02$ \\
\hline Organic-30th week & $115.53 \pm 5.44$ & $30.96 \pm 0.71$ & $20.75 \pm 0.52$ & $0.100 \pm 0.003$ & $0.105 \pm 0.008$ & $0.233 \pm 0.004$ & $0.25 \pm 0.01$ \\
\hline Organic-60th week & $172.47 \pm 9.84$ & $29.56 \pm 0.59$ & $21.77 \pm 0.61$ & $0.102 \pm 0.006$ & $0.146 \pm 0.009$ & $0.221 \pm 0.006$ & $0.21 \pm 0.01$ \\
\hline \multicolumn{8}{|l|}{$P$ value } \\
\hline Rearing system & 0.002 & 0.103 & 0.820 & 0.000 & 0.002 & 0.224 & 0.002 \\
\hline Age & 0.002 & 0.101 & 0.423 & 0.000 & 0.004 & 0.767 & 0.085 \\
\hline $\mathrm{R} \times \mathrm{A}$ & 0.001 & 0.599 & 0.363 & 0.000 & 0.758 & 0.453 & 0.480 \\
\hline
\end{tabular}




\section{AGRICULTURAL AND FOOD SCIENCE}

Y. Baykalir et al. (2020) 29: 307-317

\section{Discussion}

The results of this study, similar to those of previous studies, showed that palmitic, oleic, and linoleic acids were the most abundant fatty acids in eggs (Hidalgo et al. 2008, Samman et al. 2009, Stanišić et al. 2015). SFA levels were similar in eggs produced by both organic and conventional production systems, which is in agreement with the results of Cherian et al. (2002). In the present study, the levels of MUFA and PUFA were different according to the rearing system. Higher levels of PUFA and $n-3$ were produced in eggs from organically reared hens fed grass as a green forage material in the outdoor area (Lopez-Bote et al. 1998, Hammershoj and Johansen 2016). It has been suggested that a high level of PUFA in the hen diet causes a decrease in MUFA content in the egg yolk (Shahid et al. 2015); however, in this study, total PUFA was decreased in eggs from older hens, which suggests that the hen's bodily functions are reduced with age (Barzilai et al. 2012). Absorption in the small intestine decreases with age, which may be the cause of lower levels of PUFA as well as n-3 and n- 6 in eggs from older hens (Woudstra and Thomson 2002). Eggs from younger hens have smaller egg yolks than those from older hens; therefore, the proportion of PUFA, n-3, and n- 6 is higher in the smaller egg yolks (Nielsen 1998). Cholesterol in eggs can be altered by manipulating the hen's diet. Canola oil (Ismail et al. 2013), flaxseed (Chen et al. 2015), hemp seed (Shahid et al. 2015), and grape seed (Sun et al. 2018) were demonstrated to reduce cholesterol in eggs when added as supplements to the hens' diet. There were no differences in cholesterol content between different housing environments, and hen age had no effect on its content in the eggs (Zemková et al. 2007, Karsten et al. 2010, Anderson 2011). In contrast, Kovacs et al. (1998) have reported that cholesterol concentrations changed periodically during the laying cycle, decreasing from the beginning of the laying cycle to 45 weeks of age and increasing at 51-52 weeks of age, after which it declined to the end of laying period. In addition, the strain of hen has an effect on cholesterol levels in the eggs (Simčič et al. 2009). In this study, the amount of cholesterol was similar among both rearing systems and age groups. Karsten et al. (2010), Kucukyilmaz et al. (2012), and Anderson (2011) have indicated that rearing system has no effect on cholesterol levels in egg yolks, which supports our findings. Zemková et al. (2007) have also reported no age-related changes in cholesterol content in the eggs, which is confirmed in our study. This result could be attributed to the same layer hybrid and similar feed used in the studies. The shelf life of PUFA-rich foods is at a disadvantage because of their susceptibility to oxidative deterioration (Buckiuniene et al. 2016). In this study, MDA levels were higher in the organic eggs than in those from conventionally reared hens, which can be explained by the high proportion of PUFA in the organic eggs (Cengiz et al. 2015). Moreover, organically reared hens are exposed to environmental factors, which may stimulate the formation of cellular free radicals through the steroid synthesis mechanism in the hens (Simsek et al. 2018). Vitamin E is the common name of a group consisting of four tocopherols and four tocotrienols, creating eight natural compounds (Rizvi et al. 2014). The $\alpha$-tocopherol in this group has high biological value. The studies conducted on comparing eggs from organic and conventionally reared hens have shown that the amount of $\alpha$-tocopherol is lower in the organic eggs (Matt et al. 2009, Mugnai et al. 2009), which was similar our observation. The low level of $\alpha$-tocopherol in the organic eggs suggests that it is depleted as it protects the eggs against oxidative deterioration (Shahryar et al. 2010). Moreover, younger hens had lower $\alpha$-tocopherol levels. The $\alpha$-tocopherol levels in the eggs might also be influenced by their lipid content (PUFA, notably arachidonic acid, and docosahexaenoic acid) because $\alpha$-tocopherol is a fatsoluble compound (Lebold and Traber 2014, Takahashi et al. 2017). On the other hand, vitamin E concentrations increased with hen aging in liver. The vitamin D group includes secosteroids, such as D1 (ergocalciferol + lumisterol), D2 (ergocalciferol), D3 (cholecalciferol), D4 (22-dihydroergocalciferol), and D5 (sitocalciferol), with D2 and D3 being the most biologically important (Calvo et al. 2005). Feed and sunlight are the two most important sources of vitamin D. The vitamin D2 content in the eggs from the organic system in the current study was higher than that in eggs from the conventional system. This result is believed to be caused by the beneficial effect of the daylight and the intake of natural vegetation when the hens accessed the outdoor area. Similarly, this was also the case for the levels of vitamin K2 in the egg yolks. The alfalfa flour intake by the organically raised hens might result in a higher level of the vitamin $\mathrm{K} 2$ in the organic eggs.

\section{Conclusions}

The results of the present study showed that PUFA, $n-3$, and n- 6 were higher in the organic table eggs; however, the organic eggs were more susceptible to oxidative deterioration because of their high levels of PUFA. Vitamins $E$ and $K$ were also higher in organic eggs. We also determined that the levels of PUFA, $n-3$, and $n-6$ were higher in eggs from the younger hens. The rearing system and age also had an impact on other egg components. According to the results of the current study, rearing systems can have advantages and disadvantages in terms of egg composition; therefore, all aspects of these systems should be more fully evaluated. In the case of any rearing system preferences, beyond the quality of the eggs, the number of eggs should also not be ignored. Indeed, the number 
of the egg may be influenced negatively by organic or free-range raising system. This fact should be evaluated by considering the supply/demand balance. However, the regulations implemented by the governments should be noted in point of hen welfare in the rearing systems.

\section{Acknowledgements}

The authors acknowledge all flock owners and personnel from the egg-production company for providing the necessary materials for this study. The authors also thank Firat University Department of Scientific Research Projects (FUBAP, Grant VF.14.22), Elazig, Turkey, for its financial support.

\section{References}

Anderson, K.E. 2011. Comparison of fatty acid, cholesterol, and vitamin A and E composition in eggs from hens housed in conventional cage and range production facilities. Poultry Science 90: 1600-1608. https://doi.org/10.3382/ps.2010-01289

Barzilai, N., Huffman, D.M., Muzumdar, R.H. \& Bartke, A. 2012. The critical role of metabolic pathways in aging. Diabetes 61: 1315-1322. https://doi.org/10.2337/db11-1300

Bauernfeind, J.C. \& De Ritter, E. 2018. Nutritional supplements for animals: Vitamins. In: Rechcigl, M. (ed.). Handbook of nutritional supplements: Volume II, Agricultural use. Boca Raton, Florida, USA: CRC Press Taylor \& Francis Group. p. 3-46.

Baykalir, Y. \& Simsek, U.G. 2018. Impact of different rearing system and age on Bovans White layer's performance, egg quality traits and synthesis of heat shock protein 70 kDa. Annals of Animal Science 18: 1045-1060. https://doi.org/10.2478/aoas-2018-0027

Buckiuniene, V., Gruzauskas, R., Kliseviciute, V., Raceviciute-Stupeliene, A., Svirmickas, G., Bliznikas, S., Miezeliene, A., Alencikiene, G. \& Grashorn, M.A. 2016. Effect of organic and inorganic iron on iron content, fatty acid profile, content of malondialdehyde, texture and sensory properties of broiler meat. European Poultry Science 80: 1-14.

Calvo, M.S., Whiting, S.J. \& Barton, C.N. 2005. Vitamin D intake: A global perspective of current status. The Journal of Nutrition 135: 310-316. https://doi.org/10.1093/jn/135.2.310

Cengiz, S.S., Yesilbag. D., Meral, Y., Cetin, I. \& Biricik, H. 2015. Juniper oil improves oxidative stability and eggshell and albumin quality of quail eggs. British Poultry Science 56: 58-65. https://doi.org/10.1080/00071668.2014.988123

Chen, W., Jiang, Y.Y., Wang, J.P., Yan, B.X., Huang, Y.Q. \& Wang, Z.X. 2015. Effect of flaxseed on the fatty acid profile of egg yolk and antioxidant status of their neonatal offspring in Huoyan geese. Animal 9: 1749-1755. https://doi.org/10.1017/S1751731115001287

Cherian, G., Holsonbake, T.B. \& Goeger, M.P. 2002. Fatty acid composition and egg components of specialty eggs. Poultry Science 81: 30-33. https://doi.org/10.1093/ps/81.1.30

Cherian, G. \& Quezada, N. 2016. Egg quality, fatty acid composition and immunoglobulin Y content in eggs from laying hens fed full fat camelina or flax seed. Journal of Animal Science and Biotechnology 7: 1-8. https://doi.org/10.1186/s40104-016-0075-y Christie, W.W. 1989. Gas Chromatography and Lipids. Glasgow: The Oil Press. 307 p.

Collins, L.M., Dziak, J.J. \& Li, R. 2009. Design of experiments with multiple independent variables: a resource management perspective on complete and reduced factorial designs. Psychological Methods 14: 202-224. https://doi.org/10.1037/a0015826

Eilat-Adar, S., Sinai, T., Yosefy, C. \& Henkin, Y. 2013. Nutritional recommendations for cardiovascular disease prevention. Nutrients 5: 3646-3683. https://doi.org/10.3390/nu5093646

Hammershøj, M. \& Johansen, N.F. 2016. Review: The effect of grass and herbs in organic egg production on egg fatty acid composition, egg yolk colour and sensory properties. Livestock Science 194: 37-43. https://doi.org/10.1016/j.livsci.2016.11.001

Hara, A. \& Radin, N.S. 1978. Lipid extraction of tissues with a low-toxicity solvent. Analytical Biochemistry 90: 420-426. https://doi.org/10.1016/0003-2697(78)90046-5

Hidalgo, A., Rossi, M., Clerici, F. \& Ratti, S. 2008. A market study on the quality characteristics of eggs from different housing systems. Food Chemistry 106: 1031-1038. https://doi.org/10.1016/j.foodchem.2007.07.019

Hu, J., Zhang, Z., Shen, W.J. \& Azhar, S. 2010. Cellular cholesterol delivery, intracellular processing and utilization for biosynthesis of steroid hormones. Nutrition \& Metabolism 7: 1-25. https://doi.org/10.1186/1743-7075-7-47

Huber, M., Van De Vijver, L.P., Parmentier, H., Savelkoul, H., Coulier, L., Wopereis, S., Verheij, E., Van Der Greef, J., Nierop, D. \& Hoogenboom, R.A. 2010. Effects of organically and conventionally produced feed on biomarkers of health in a chicken model. British Journal of Nutrition 103: 663-676. https://doi.org/10.1017/S0007114509992236

İlhan, M. \& Bülbül, T. 2016. Effect of retinol and retinol esters on performance, egg quality, and blood and egg vitamin A levels in laying quails. Turkish Journal of Veterinary and Animal Sciences 40: 590-597. https://doi.org/10.3906/vet-1506-100

Ismail, E.B., Al-Busadah, K.A. \& El-Bahr, S.M. 2013. Effect of dietary supplementation of canola oil on egg production, quality and biochemistry of egg yolk and plasma of laying hen. International Journal of Biological and Chemical Sciences 7: $27-37$. https://doi.org/10.3923/ijbc.2013.27.37

Karatas, F., Karatepe, M. \& Baysar, A. 2002. Determination of free malondialdehyde in human serum by high-performance liquid chromatography. Analytical Biochemistry 311: 76-79. https://doi.org/10.1016/S0003-2697(02)00387-1

Karsten, H.D., Patterson, P.H., Stout, R. \& Crews, G. 2010. Vitamins A, E and fatty acid composition of the eggs of caged hens and pastured hens. Renewable Agriculture and Food Systems 25: 45-54. https://doi.org/10.1017/S1742170509990214 
Kovacs, G., Dublecz, K., Husveth, F., Wagner, L., Gerendaid, D., Orban, J. \& Manilla, H. 1998. Effect of different hybrids, strains and age of laying hens on the cholesterol content of the table egg. Acta Veterinaria Hungarica 46: 285-294.

Kristiansen, P., Taji, A. \& Reganold, J. 2006. Organic agriculture: opportunities and challenges. In: Kristiansen, P. (ed.). Organic agriculture: A global perspective. Oxfordshire, Wallingford, UK: Cabi. p. 421-441. https://doi.org/10.1079/9781845931698.0421

Küçükyılmaz, K., Bozkurt, M., Herken, E.N., Çınar, M., Çatlı, A.U., Bintaş, E. \& Çöven, F. 2012. Effects of rearing systems on performance, egg characteristics and immune response in two layer hen genotype. Asian-Australasian Journal of Animal Sciences $25:$ 559-568. https://doi.org/10.5713/ajas.2011.11382

Lauridsen, C., Jorgensen, H., Halekon, U., Lars-Porsjer, C. \& Brandt, K. 2005. Organic diet enhanced the health of rats. Newsletter Danish Resource Centre Organic Food Systems $1: 2-11$.

Lebold, K.M. \& Traber, M.G. 2014. Interactions between alpha-tocopherol, polyunsaturated fatty acids, and lipoxygenases during embryogenesis. Free Radical Biology and Medicine 66: 13-19. https://doi.org/10.1016/j.freeradbiomed.2013.07.039

Li, Y., Zhou, C., Zhou, X. \& Li, L. 2013. Egg consumption and risk cardiovascular diseases and diabetes: A meta-analysis. Atherosclerosis 229: $524-530$. https://doi.org/10.1016/j.atherosclerosis.2013.04.003

Liu, L.Y. \& Lee, M.H. 1996. Effects of hen's age on the composition of yolk lipid. Food Science (Taiwan) 23: 168-173.

Lopez-Bote, C.J., Sanz Arias, R., Rey, A.I., Castaño, A., Isabel, B. \& Thos, J. 1998. Effect of free range feeding on n-3 fatty acid and alpha-tocopherol content and oxidative stability of eggs. Animal Feed Science and Technology 72: 33-40.

https://doi.org/10.1016/S0377-8401(97)00180-6

Lopez-Cervantes, J., Sanchez-Machado, D.I. \& Rios-Vazquez, N.J. 2006. High performance liquid chromatography method for the simultaneous quantification of retinol, alpha-tocopherol, and cholesterol in shrimp waste hydrolysate. Journal of Chromatography A 1105: 135-139. https://doi.org/10.1016/j.chroma.2005.08.010

Matt, D., Veromann, E. \& Luik, A. 2009. Effect of housing systems on biochemical composition of chicken eggs. Agronomy Research 7: 662-667.

Miranda, J.M., Anton, X., Redondo-Valbuena, C., Roca-Saavedra, P., Rodriguez, J.A., Lamas, A., Franco, C.M. \& Cepeda, A. 2015. Egg and egg-derived foods: effects on human health and use as functional foods. Nutrients 7: 706-729. https://doi.org/10.3390/nu7010706

Mohiti-Asli, M., Shariatmadari, F., Lotfollahian, H. \& Mazuji, M.T. 2008. Effects of supplementing layer hen diets with selenium and vitamin E on egg quality, lipid oxidation and fatty acid composition during storage. Canadian Journal of Animal Science 88: 475-483. https://doi.org/10.4141/CJAS07102

Mugnai, C., Dal Bosco, A. \& Castellini, C. 2009. Effect of rearing system and season on the performance and egg characteristics of Ancona laying hens. Italian Journal of Animal Science 8: 175-188. https://doi.org/10.4081/ijas.2009.175

NRC 1994. Nutrient Requirements of Poultry. 9th rev. ed. Washington DC: National Academy of Science. $19 \mathrm{p}$.

Nielsen, H. 1998. Hen age and fatty acid composition of egg yolk lipid. British Poultry Science 39: 53-56. https://doi.org/10.1080/00071669889394

Orth, M. \& Bellosta, S. 2012. Cholesterol: Its regulation and role in central nervous system disorders. Cholesterol 2012:1-19. https://doi.org/10.1155/2012/292598

Papastergiadis, A., Mubiru, E., Van Langenhove, H. \& De Meulenaer, B. 2012. Malondialdehyde measurement in oxidized foods: Evaluation of the spectrophotometric thiobarbituric acid reactive substances (TBARS) test in various foods. Journal of Agricultural and Food Chemistry 60: 9589-9594. https://doi.org/10.1021/jf302451c

Radu-Rusu, R.M., Usturoi, M.G., Leahu, A., Amariei, S., Radu-Rusu, C.G. \& Vacaru-Opriş, I. 2014. Chemical features, cholesterol and energy content of table hen eggs from conventional and alternative farming systems. The South African Journal of Animal Science 44: 33-42. https://doi.org/10.4314/sajas.v44i1.5

Ristić-Medić, D., Vučić, V., Takić, M., Karadžić, I. \& Glibetić, M. 2013. Polyunsaturated fatty acids in health and disease. Publications of the Serbian Chemical Society 78: 1269-1289. https://doi.org/10.2298/JSC130402040R

Rizvi, S., Raza, S.T., Ahmed, F., Ahmad, A., Abbas, S. \& Mahdi, F. 2014. The role of Vitamin E in human health and some diseases. Sultan Qaboos University Medical Journal 14: 157-165.

Rymer, C. \& Givens, I. 2005. n-3 fatty acid enrichment of edible tissue of poultry: A review. Lipids 40: 121-130. https://doi.org/10.1007/s11745-005-1366-4

Samman, S., Kung, F.P., Carter, L.M., Foster, M.J., Ahmad, Z.I., Phuyal, J.L. \& Petocz, P. 2009. Fatty acid composition of certified organic, conventional and omega-3 eggs. Food Chemistry 116: 911-914. https://doi.org/10.1016/j.foodchem.2009.03.046

Sánchez-Machado, D.I., López-Hernández, J. \& Paseiro-Losada, P. 2002. High performance liquid chromatographic determination of alpha-tocopherol in macro algae. Journal of Chromatography A 976: 277-284. https://doi.org/10.1016/S0021-9673(02)00934-2

Sarwar, G. 1997. The protein digestibility-corrected amino acid score method overestimates quality of proteins containing antinutritional factors and of poorly digestible proteins supplemented with limiting amino acids in rats. The Journal of Nutrition 127:758-764. https://doi.org/10.1093/jn/127.5.758

Scheideler, S.E., Jaroni, D. \& Froning, G. 1998. Strain and age effects on egg composition from hens fed diets rich in n-3 fatty acids. Poultry Science 77: 192-196. https://doi.org/10.1093/ps/77.2.192

Shahid, S., Chand, N., Khan, R.U., Suhail, S.H. \& Khan, N.A. 2015. Alternations in cholesterol and fatty acids composition in egg yolk of Rhode Island Red x Fyoumi Hens fed with hemp seeds (Cannabis sativa L.). Journal of Chemistry 2015: 1-6. https://doi.org/10.1155/2015/362936

Shahryar, H.A., Salamatdoust, R., Chekani-Azar, S., Ahadi, F. \& Vahdatpoor, T. 2010. Lipid oxidation in fresh and stored eggs enriched with dietary $\omega 3$ and $\omega 6$ polyunsaturated fatty acids and vitamin $E$ and A dosages. African Journal of Biotechnology 9 : 1827-1832. https://doi.org/10.5897/AJB10.1482 


\section{AGRICULTURAL AND FOOD SCIENCE}

Y. Baykalir et al. (2020) 29: 307-317

Simčič, M., Stibilj, V. \& Holcman, A. 2009. The cholesterol content of eggs produced by the Slovenian Autochthonous Styrian hen. Food Chemistry 114: 1-4. https://doi.org/10.1016/j.foodchem.2008.09.110

Simsek, U.G., Baykalir, Y., Erisir, M. \& Benzer, F. 2018. Effects of conventional and organic rearing systems and hen age on oxidative stress parameters of blood and ovarian tissues in laying hens. Veterinary Journal of Ankara University 65: 85-91. https://doi.org/10.1501/Vetfak_0000002832

Stanišić, N., Petričević, V., Škrbić, Z., Lukić, M., Pavlovski, Z., Lilić, S. \& Petričević, M. 2015. Effects of age and time of day of sampling on proximate and fatty acid composition of whole eggs from two strains of laying hens. Archives Animal Breeding 58: 151158. https://doi.org/10.5194/aab-58-151-2015

Sun, P., Lu, Y., Cheng, H. \& Song, D. 2018. The effect of grape seed extract and yeast culture on both cholesterol content of egg yolk and performance of laying hens. The Journal of Applied Poultry Research 27: 564-569. https://doi.org/10.3382/japr/pfy035

Takahashi, K., Takisawa, S., Shimokado, K., Kono, N., Arai, H. \& Ishigami, A. 2017. Age-related changes of vitamin E: $\alpha$-tocopherol levels in plasma and various tissues of mice and hepatic $\alpha$-tocopherol transfer protein. European Journal of Nutrition 56: 13171327. https://doi.org/10.1007/s00394-016-1182-4

Tvrzická, E., Vecka, M., Staňková, B. \& Žák, A. 2002. Analysis of fatty acids in plasma lipoproteins by gas chromatography flame ionisation detection quantitative aspects. Analytica Chimica Acta 465: 337-350. https://doi.org/10.1016/S0003-2670(02)00396-3

Vogtmann, H. 1998. From healthy soil to healthy food: An analysis of the quality of food produced under contrasting agricultural system. Nutrition and Health 6: 21-35. https://doi.org/10.1177/026010608800600103

Woods, V.B. \& Fearon, A.M. 2009. Dietary sources of unsaturated fatty acids for animals and their transfer into meat, milk and eggs: A review. Livestock Science 126: 1-20. https://doi.org/10.1016/j.livsci.2009.07.002

Woudstra, T. \& Thomson, A.B.R. 2002. Nutrient absorption and intestinal adaptation with ageing. Best Practice \& Research Clinical Gastroenterology 16: 1-15. https://doi.org/10.1053/bega.2001.0262

Zemková, L., Simeonovová, J., Lichovníková, M. \& Somerlíková, K. 2007. The effects of housing systems and age of hens on the weight and cholesterol concentration of the egg. Czech Journal of Animal Science 52: 110-115. https://doi.org/10.17221/2269-CJAS 